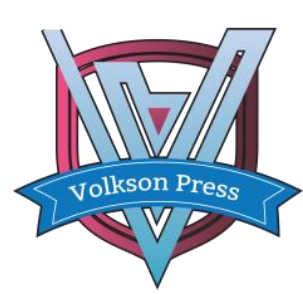

Contents List available at VOLKSON PRESS

Economics \& Management Innovations(EMI)

DOI : http://doi.org/10.26480/icemi.01.2017.183.184

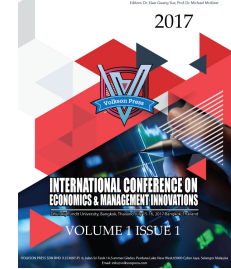

\title{
The Influence of Service Leadership on Well-being in Workplace: Using Workplace Friendship as an Mediator Variable and Self-Efficacy and Emotional Intelligence as Moderating Variables
}

\author{
Zang Ge-ge ${ }^{1}$, Chen Chun-shuo ${ }^{2 *}$ \\ ${ }^{1}$ Dhurakij Pundit University, China-ASEAN International College, Bangkok, Thailand \\ ${ }^{2}$ Dhurakij Pundit University, China-ASEAN International College, Bangkok, Thailand \\ email:407896252@qq.com
}

This is an open access article distributed under the Creative Commons Attribution License, which permits unrestricted use, distribution, and reproduction in any medium, provided the original work is properly cited.

\section{ARTICLE DETAILS}

\section{Article History:}

Received 02 october 2017 Accepted 06 october 2017 Available online 11 october 2017

\section{Keywords:}

Service Leadership, Self efficacy, Workplace Friendship, Emotional Intelligence, Work Happiness.

\section{ABSTRACT}

The purpose of this study is to explore the relationship between service leadership and self-efficacy, workplace friendship, emotional intelligence and work happiness. How to improve the work happiness of the staff and to mobilize their enthusiasm and creativity, improve work efficiency, solidarity from the perspective of service leadership, it will be the innovation of this study to explore. This study draws the following conclusions: (1) Service leadership is positively related to work happiness, and the leader's service for the staff can better improve the work happiness of the staff; (2) Service leadership is a positively related to the workplace friendship and the leaders' service to the staff enhance the interpersonal relationship in the comfortable environment; (3) The employee's self-efficacy and emotional intelligence have a significant impact on the service-oriented leadership.

\section{Introduction}

Past leadership theory models are mostly based on the authorization and command and hierarchical structure. Althoughthe leadership style canimprove the operational efficiency of the organizationto a certain extent, it is difficult to adapt to the requirements of the times. Based on the story "Travel to the East", American scholars proposed servant leadershipjustto solve this problem. It is encouragingthat some companies have become pioneers in the practice of building employees'work happiness. In addition to the workhappiness, workplace friendship and emotional intelligence have also become a focus of attention in academic and practical fields in recent years.

Current research on the relations in the workplace is mainly focused on the negative aspects of theworkplace relations, on the contrary, positive variables such as friendship, mutual workplace assistance in the workplace are neglected in the research. Therefore it is necessary in theory to conduct research on workplace friendship which has more theoretical significance. The more organizers and managers conductresearch on the positive impact of workplace friendship, the more likely theywill lookthroughrose-colored glasses. Servant leadership can increase employees' trust in organization and leadership, and help managers understand the important function of the leadership-employee relations in the workplace, and meanwhile help employees to realize the importance of good relations with leaders.

\section{Literature Review and Hypotheses Development}

Spears (1988) provided an understanding of servant leadership: leaders always adhere to the concept of service first, senior leaders respect colleagues and subordinates while listening to their opinions and suggestions and establish teamwork and coordinate community building, and build good interpersonal relations(Russell \& Gregory Stone, 2002). Sias and Cahill (1998) believed that workplace friendship not only developed between equal colleagues, but also between supervisors and subordinates. Yan (2014) pointed out that workplace friendship developed between colleagues in the workplace. Also, Zhang (2014) believed that workplace friendship was a special form of friendship, was a special form of friendship which developed from social emotions. It was strongly of a workplace type, linked to the development environment, quality, personal behavior and organization of the workplace friendship.

Pressley(1990) confirmed that students with high self-efficacy have a strong self-monitoring ability, which has a positive impact on their learning achievement.Within the organization, the high self-efficacy, as the best predictor of performance, can significantly influence the growth of the performance. High self-efficacy can encourage individuals to challenge difficult tasks, and to show stronger goal commitment, thus they will be able to improve individual work performance (Zimmerman, Bandura, \& Martinez-Pons, 1992).

McClelland's (1975) study found that the remarkable differences between excellent employees and ordinary employees mainly lies in the differences of emotional intelligence, including self-confidence, leadership, flexibility, motivation, and IQ only has small differences (Boyatzis, Goleman, \& Rhee, 2000). Wu (2008) pointed out the future research direction. He believed that emotions had an influence on personal performance, attitude, happiness, human judgment, service providers, and customers. Lai (2015) considered that an individual's perception of emotions led to understanding, reasoning, judgment, and application of various information to deal with things. Application to individuals helps individuals build positive rich life; Application to interpersonal relationships can create a harmonious interpersonal network (Wang, 2016). According to above mentioned, this study offers the following hypotheses:

H1: Servant leadership has a positive effect on work happiness.

H2: Servant leadership has a positive effect on workplace friendships.

H3: Workplace friendship has a positive effect on work happiness.

H4: Servant leadership has a positive effect on work happiness via workplace friendship.

H5: With the increase of self-efficacy, servant leadership has a stronger positive effect on workplace friendship. 
H6: With the increase of emotional intelligence, servant leadership has a stronger positive effect on workplace friendship.

H7: With the increase of emotional intelligence, workplace friendship has a stronger positive effect on work happiness.

\section{Methodology}

\subsection{Research Framework}

The aim of this study is to give a detailed description of servant leadership. With local companies as the research object, this study discusses the application of servant leadership theory in Chinese context, especially the relations between servant leadership and workplace friendship and work happiness in order to employ this theory to improve the quality of the Chinese business leaders and leadership. This study is focused on the relations between servant leadership, self-efficacy, workplace friendship, emotional intelligence and work happiness. The research framework of this study is given as follows.

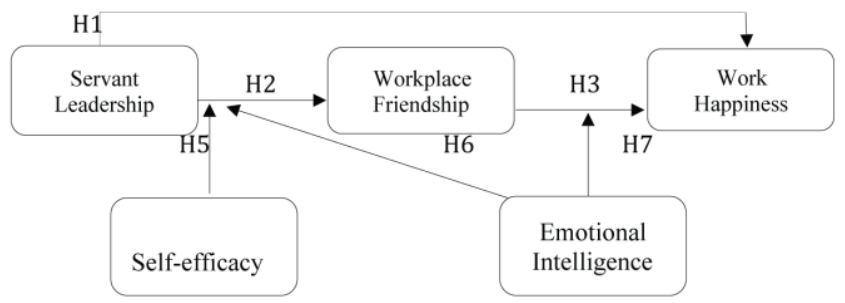

Figure 1 Research Framework

\subsection{Date collection and analysis}

The data collection was mainly done online. Online survey was done mainly via questionnaire, E-mail and instant messaging software. The questionnaire was distributed to the respondents who were asked to fill out the questionnaire online so as to ensure the effectiveness and accuracy of the data collection.

The model structure of this study was mainly for enterprise employees as the objects of the open questionnaire. In order to achieve better and more effective data analysis, 511 copies of the questionnaire were issued, afterwards all were collected. Before the formal questionnaire, 30 copies were issued to test the questionnaire's validity. The questionnaire was distributed to employees in the form of on-the-spot distribution.

The data analysis tools of the study were SPSS 19.0 and AMOS 21.0 statistical analysis software.The statistical analysis of the data was described as follows. (1) Descriptive analysis: mainly by using frequency analysis method to make statistics of the collected questionnaire's respondents. This study used descriptive statistical analysis to understand the average and standard deviation of the sample respondents allocation proportion. (2) Reliability and validity analysis: The test of validity and reliability of the measurement options in the scale. (3) Correlation analysis: it was mainly focused on the relative coefficients of each variable to determine the existence of the relative coefficients and their magnitude.The purpose was to see if there was a significant correlation between the variables. (4) Regression analysis: To explore the relations between the two variables, the regulatory effect which affected the relations between the variables. To understand the joint predictive power of the predicted variables so as to test the hypothesis proposed in this study.

\section{Conclusion}

\subsection{Research Result}

The research results of this study found that leaders were able to enhance the work happiness of their employees by adopting a servant leadership style. By their own actions, servant leaders can make their followers become more active, positive, smart, free. The followers will actively gather around the organization's goals, continuously improve the selfmanagement and service ability, consciously protectand achieve theorganization'sgoalstoimprove thehappiness at work. Influenced by servant leadership style, interpersonal relations are more harmonious.
Interpersonal similarities also influence work place friendship which has a positive impact on the happiness at work. The results of this study show that self-efficacy is the self-confidence of the individuals in coping with the challenges in different environments or facing new things. Also, emotional intelligence is a kind of abilitytoevaluate their ownemotions, to evaluate the emotions of others, to express emotions, and to adjust and control emotions. When employees' emotional intelligence and self-efficacy is high, their own self-confidence and self-awareness and control willbe higherintheworkplace. Servant leadership style plays a major role in employees getting along with their leaders, and employees getting along with other employees. Self-efficacy, emotional intelligence and workplace friendship can play a more important role in improving the work happiness.

\subsection{Suggestions and Limitations}

Leaders possess positional advantages, but at the same time, they should also have their own unique insights in their field. Enterprise managers should make full use of advantages in these two aspects to guide employees in the work and let them gain big progress space. The leaders should also take care of the employees living, value the employees, have close communication with their employees, and shows servant leadership awareness in the process of communication. An incentive mechanism is vital for valuable employees. To show more concern for personal development, to provide training courses for the employees, and to meet the needs of employees' personal growth can make employees become more loyal to the enterprise. Thus, the employees will work even harder. The human resources department can organize team activities to enhance feelings between the organization and employees, and make use of after work sports activities to cultivate the friendship between the employees aswell. Let the employees grow together with the organization.

Due to some limitations of the research design and methodology, there are some short comings in this research, which needs to be improved and perfected in future studies. Due to the limitation of time and conditions, the collected data are not adequate. In real life, these research variables are changing constantly. Therefore studying them should be a long-term process in order to get a more credible research conclusion. This study mainly adopts a single study in the selection of variables. It has not studied the segmentation of variables, and the research level is simple. The research is not deep enough, and the results are yet to be dug deep. For future studies, more has to be done in servant leadership, workplace friendship and work happiness in order to get more accurate results.

\section{References}

[1] Boyatzis, R. E., Goleman, D., \& Rhee, K. (2000). Clustering competence in emotional intelligence: Insights from the Emotional Competence Inventory (ECI). Handbook of emotional intelligence, 99(6), 343-362.

[2] Russell, R. F., \& Gregory Stone, A. (2002). A review of servant leadership attributes: Developing a practical model. Leadership \& Organization Development Journal, 23(3), 145-157.

[3] Sias, P. M., \& Cahill, D. J. (1998). From coworkers to friends: The development of peer friendships in the workplace. Western Journal of Communication (includes Communication Reports), 62(3), 273-299.

[4] Wang, C. W. (2016). The influence of incentive systems and organizational loyalty on job performance. Huwei University of Science and Technology, Department of Business Administration Management, Master degree thesis, 1-82.

[5] Wu, Z. (2008). From improper supervision to emotional exhaustion: subordinate sense of justice and emotional labor intermediary effect. Chinese Journal of Psychology, 50(2), 201-221.

[6] Yan, P. (2014). The success of workplace friendship. Counseling and Coaching (342), 50-53.

[7] Zimmerman, B. J., Bandura, A., \& Martinez-Pons, M. (1992). Selfmotivation for academic attainment: The role of self-efficacy beliefs and personal goal setting. American Educational Research Journal, 29(3), 663676.

[8] Zhang, X. Z. (2014). New field of workplace management - research on workplace friendship. Foreign Economy and Management, 36 (3), 49-55. 